\title{
A STUDY OF THE REPEATABILITY OF VENTILATORY TESTS, ANTHROPOMETRIC MEASUREMENTS, AND ANSWERS TO A RESPIRATORY SYMPTOMS QUESTIONNAIRE IN WORKING COAL-MINERS
}

\author{
BY \\ J. R. ASHFORD, G. D. FORWELL, and R. ROUTLEDGE \\ From the Pneumoconiosis Field Research of the National Coal Board
}

(RECEIVED FOR PUBLICATION OCTOBER 3, 1958)

A study has been made in working coal-miners of the repeatability of ventilatory tests, anthropometric measurements, and the answers to a questionnaire on respiratory symptoms.

On the first visit especially, there was evidence of a continuous increase in both forced expiratory volume (F.E.V.) and forced vital capacity (F.V.C.) from the first to sixth expirations at the same visit but it was minimal after the first expiration. No difference between the beginning and end of a shift was found. The effect on the F.E.V. and F.V.C. readings of the day of the week and time of day at which the examination was made was negligible. The observations recorded in Scotland were $15 \%$ higher than those obtained in South Wales.

Between the beginning and end of shift there was a small reduction in weight and in standing and sitting height measurements.

The repeatability of the answers to the questionnaire was good. No consistent difference was found between doctor and clerk observers.

In 1956 it was decided to include follow-up studies of ventilatory function as part of the medical examinations carried out by the Pneumoconiosis Field Research of the National Coal Board (Fay, 1957; Fay and Rae, 1959). In routine surveys in this scheme the mineworkers are all volunteers. This implies that they may present themselves for examination on any day of the week and either before or after working a shift. It was therefore considered necessary to examine the reproducibility of the proposed measurements. Investigations were carried out at a colliery in Fife and a colliery in South Wales before the routine surveys were started, to study the following factors:-

(1) The variability in the measurements of the one-second forced expiratory volume (F.E.V.) and forced vital capacity (F.V.C.) at the same visit; (2) the effect of working a shift; (3) the effect of the time of day at which the man was examined; (4) the effect of the day of the week on which the man was examined; (5) the observer error when making measurements of F.E.V., F.V.C., standing height, sitting height, and weight; (6) the reproducibility of a short questionnaire on respiratory symptoms.

\section{Design}

The design of the trial was conditioned by the need to investigate the effect of the day of the week and the time of day at which the various tests were applied. As it was thought that the age and occupation of the subject might also have some effect on the results, account was also taken of these factors. At each colliery the working population was divided into five arbitrary age classes (under 30 years, 31-40, 41-50, 51-60, and 60 and over) and five arbitrary occupational classes, of which two covered faceworkers, two covered non-faceworkers underground, and one covered surface workers. Each of these 25 groups was further subdivided into three subgroups, in terms of shift worked (days, afternoons, or nights) on the first of the two weeks during which the trial was carried out. The subjects for examination were then chosen at random, one from each of the 75 subgroups. To obtain a balance between the days of examination on the first and second weeks of the trial and between the five age and five employment classes a $5 \times 5$ Graeco-Latin square design was applied for each of the three shifts worked on the first week of the trial. In this way one man working on each of the day, afternoon 
and night shifts on the first week of the trial was examined on each of the 25 possible combinations, that is (Mon., Mon.), (Mon., Tu.), (Mon., Wed.), . . . (Th., F.), (F.F), of days of examination on the first and second weeks. Each man was examined four times in all, before (visit 1) and after (visit 2) the working shift on the specified day of the first week and before (visit 3) and after (visit 4) the working shift on the second week of the trial. The majority of men worked a different shift on the first and second weeks. When any of the selected subjects was absent on the first week of the trial a reserve chosen at random from the appropriate subgroup was included in his place. No man refused to cooperate and all men carried out the four visits, although a few did not report on the specified day on the second week and were examined on another day later in the same week.

It must be emphasized that the Graeco-Latin square design was used solely to obtain a satisfactory balance between the various factors which were thought to be relevant. The statistical treatment conventionally adopted for designs of this type was not, in fact, applied, in view of the doubts about the validity in this particular application of some of the assumptions on which such analyses are based, and each factor was examined separately in the analysis of the results. For this reason the minor deviations from the design can have no appreciable effect on the analysis nor on the validity of the various conclusions which have been derived.

\section{Procedure}

On each of his four visits, the following measurements were made on each man:

(1) Six replicate readings of F.E.V. and F.V.C. (in litres) were made by a Gaensler type spirometer with an electronic timing device (Gaensler, 1951) as modified by the M.R.C. Pneumoconiosis Research Unit (Carpenter, Cochrane, Gilson, and Higgins, 1956). With this apparatus, error arising from differences in abruptness of starting expiration is reduced by starting the timing cycle after the expulsion of the first $100 \mathrm{ml}$. of air. The calibrations of four new models of this apparatus were checked and compared by the introduction of known volumes of air from a test rig at the M.R.C. Unit and their timing cycles set using a chronotron. The calibration was checked before each examination session by confirming that when a weight attached round the pulley was allowed to fall the volume recorded on the scale was constant. During each session the water round the bell was kept at $20 \pm 2^{\circ} \mathrm{C}$. McKerrow, McDermott, Gilson, and Schilling (1958) found that the volume measurement of a similar piece of apparatus was accurate to $\pm 1.5 \%$ and the time to $\pm 2.0 \%$. All measurements were made by one Scottish and one Welsh observer.

(2) At both collieries separate measurements were made by each of two observers of weight, standing height, and sitting height.

(3) Respiratory symptoms were recorded using a questionnaire similar to that used by Higgins, Oldham, Cochrane, and Gilson (1956). The questionnaire was asked of each man on both weeks of the trial, once by a doctor and once by a clerk. A randomization was applied to determine whether doctor or clerk applied the questionnaire first and also whether this was before or after shift. To minimize any observer effect extra probing questions were not allowed (Wood, 1958).

\section{Results}

\section{(A) Ventilatory Capacity}

(1) Variation within Visits.-At the first visit the variation in the average F.E.V. and F.V.C. with expiration number and age is shown in Table 1. All four visits are taken together in Fig. 1. At both collieries the differences in both F.E.V. and F.V.C. between expiration 1 and the average of expirations 2-6 were significant. The order of magnitude of these differences was about $1 \%$ for the colliery in Scotland and $2 \%$ for the colliery in South Wales. In Scotland a single practice estimation of the F.E.V. and F.V.C. was carried out in all subjects at an introductory visit. In South Wales there was no such introductory visit and the subject's first expiration on visit 1 was his first experience of the equipment. The rise in F.E.V. and F.V.C. with expiration number was less marked with increasing age (Table 1) and was less apparent in surface than in faceworkers. Values for expiration 1 were rejected in all subsequent analyses.

(2) Variation between Beginning and End of Shift.-The variation in the ventilatory and anthropometric measurements between the beginning and end of the shift may be examined by comparing the average results obtained on each visit (Fig. 2). Visits 1 and 2 were made at the beginning and end of the first shift on which the man was examined and visits 3 and 4 were made at the beginning and end of the second shift. The main feature of the observations was the fall in both F.E.V. and F.V.C. on visit 3, which was most marked at the Scottish colliery. There was no evidence of any consistent difference between the beginning and the end of the shift at either colliery. The differences between F.V.C. values for visit 3 and the mean of visits 1,2 , and 4 were of the order of $1 \%$ in Scotland and $0.5 \%$ in South Wales. The corresponding differences for F.E.V. were both about $2 \%$. When the effect of occupation is taken into account (Table 2) it will be seen that the greatest decrease on visit 3 was in faceworkers and the least in surfaceworkers. Table 3 shows that the tendency for the F.E.V. and 
TABLE $1^{*}$

F.E.V. AND F.V.C. IN TERMS OF AGE AT VISIT 1 ONLY

\begin{tabular}{|c|c|c|c|c|c|c|c|c|}
\hline \multirow{2}{*}{ Colliery } & \multirow{2}{*}{ Age (Years) } & \multicolumn{6}{|c|}{ Expiration No. } & \multirow{2}{*}{$\begin{array}{c}\text { Mean of } \\
\text { Expirations } \\
(2-6)\end{array}$} \\
\hline & & 1 & 2 & 3 & 4 & 5 & 6 & \\
\hline $\begin{array}{l}\text { (a) Average } F \\
\text { Scottish }\end{array}$ & $\begin{array}{l}\text {. (litres) } \\
\text { Under } 30 \\
30-39 \\
40-49 \\
50-59 \\
60 \text { and over }\end{array}$ & $\begin{array}{l}3 \cdot 903 \\
3 \cdot 213 \\
2 \cdot 817 \\
2 \cdot 333 \\
2 \cdot 200\end{array}$ & $\begin{array}{l}3 \cdot 870 \\
3 \cdot 247 \\
2 \cdot 903 \\
2 \cdot 327 \\
2 \cdot 207\end{array}$ & $\begin{array}{l}3 \cdot 890 \\
3 \cdot 310 \\
2 \cdot 937 \\
2 \cdot 333 \\
2 \cdot 200\end{array}$ & $\begin{array}{l}4 \cdot 000 \\
3 \cdot 370 \\
2 \cdot 940 \\
2 \cdot 353 \\
2 \cdot 227\end{array}$ & $\begin{array}{l}3.953 \\
3.377 \\
2.963 \\
2.380 \\
2 \cdot 210\end{array}$ & $\begin{array}{l}4 \cdot 027 \\
3 \cdot 393 \\
3 \cdot 007 \\
2 \cdot 393 \\
2 \cdot 243\end{array}$ & $\begin{array}{l}3 \cdot 948 \\
3 \cdot 339 \\
2 \cdot 950 \\
2 \cdot 357 \\
2 \cdot 217\end{array}$ \\
\hline $\begin{array}{l}\text { (b) Average } F \\
\text { Scottish }\end{array}$ & $\begin{array}{l}\text { C. (litres) } \\
\text { Under } 30 \\
30-39 \\
40-49 \\
50-59 \\
60 \text { and over }\end{array}$ & $\begin{array}{l}4 \cdot 813 \\
4 \cdot 713 \\
4 \cdot 373 \\
3 \cdot 917 \\
3 \cdot 420\end{array}$ & $\begin{array}{l}4.820 \\
4.723 \\
4.423 \\
3.913 \\
3.473\end{array}$ & $\begin{array}{l}4 \cdot 870 \\
4 \cdot 750 \\
4 \cdot 490 \\
3 \cdot 890 \\
3 \cdot 390\end{array}$ & $\begin{array}{l}4.900 \\
4.740 \\
4.470 \\
3.933 \\
3.410\end{array}$ & $\begin{array}{l}4.900 \\
4.720 \\
4.473 \\
3.923 \\
3.450\end{array}$ & $\begin{array}{l}4 \cdot 833 \\
4.713 \\
4.427 \\
3.927 \\
3.433\end{array}$ & $\begin{array}{l}4 \cdot 875 \\
4 \cdot 729 \\
4 \cdot 457 \\
3 \cdot 917 \\
3 \cdot 431\end{array}$ \\
\hline South Wales & $\begin{array}{l}\text { Under } 30 \\
30-39 \\
40-49 \\
50-59 \\
60 \text { and over }\end{array}$ & $\begin{array}{l}4 \cdot 525 \\
3 \cdot 844 \\
3 \cdot 220 \\
3 \cdot 316 \\
2 \cdot 650\end{array}$ & $\begin{array}{l}4 \cdot 593 \\
3.982 \\
3 \cdot 360 \\
3 \cdot 306 \\
2 \cdot 646\end{array}$ & $\begin{array}{l}4.693 \\
4.015 \\
3.307 \\
3.372 \\
2.661\end{array}$ & $\begin{array}{l}4 \cdot 725 \\
4 \cdot 047 \\
3 \cdot 340 \\
3 \cdot 341 \\
2 \cdot 636\end{array}$ & $\begin{array}{l}4 \cdot 739 \\
4 \cdot 021 \\
3 \cdot 317 \\
3 \cdot 278 \\
2 \cdot 661\end{array}$ & $\begin{array}{l}4 \cdot 579 \\
3.991 \\
3.363 \\
3.407 \\
2.650\end{array}$ & $\begin{array}{l}4 \cdot 666 \\
4 \cdot 011 \\
3 \cdot 337 \\
3 \cdot 340 \\
2 \cdot 651\end{array}$ \\
\hline
\end{tabular}

*Each entry is the mean of 15 expirations

TABLE 2

VARIATION IN F.E.V. AND F.V.C. FROM VISIT TO VISIT IN TERMS OF OCCUPATION (EXPIRATIONS 2-6)

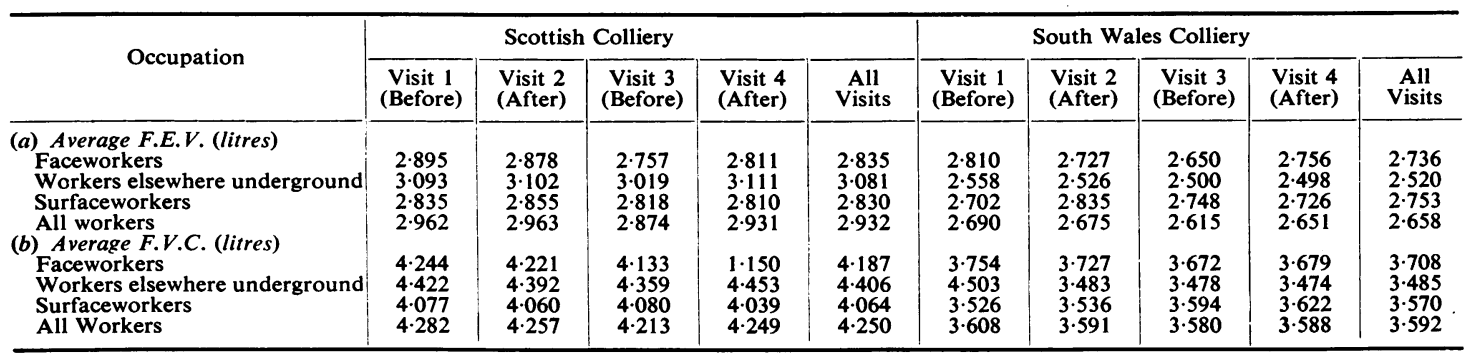

TABLE 3

VARIATION IN F.E.V. AND F.V.C. FROM VISIT TO VISIT IN TERMS OF AGE (EXPIRATIONS 2-6)

\begin{tabular}{|c|c|c|c|c|c|c|c|c|c|c|}
\hline \multirow{2}{*}{ Age (Years) } & \multicolumn{5}{|c|}{ Scottish Colliery } & \multicolumn{5}{|c|}{ South Wales Colliery } \\
\hline & $\begin{array}{l}\text { Visit 1 } \\
\text { (Before) }\end{array}$ & $\begin{array}{l}\text { Visit } 2 \\
\text { (After) }\end{array}$ & $\begin{array}{l}\text { Visit } 3 \\
\text { (Before) }\end{array}$ & $\begin{array}{l}\text { Visit } 4 \\
\text { (After) }\end{array}$ & $\begin{array}{c}\text { All } \\
\text { Visits }\end{array}$ & $\begin{array}{l}\text { Visit 1 } \\
\text { (Before) }\end{array}$ & $\begin{array}{l}\text { Visit } 2 \\
\text { (After) }\end{array}$ & $\begin{array}{l}\text { Visit } 3 \\
\text { (Before) }\end{array}$ & $\begin{array}{l}\text { Visit } 4 \\
\text { (After) }\end{array}$ & $\begin{array}{c}\text { All } \\
\text { Visits }\end{array}$ \\
\hline $\begin{array}{l}\text { Under } 30 \\
30-39 \\
40-49 \\
50-59 \\
60-69 \\
\text { All age groups }\end{array}$ & $\begin{array}{l}4 \cdot 875 \\
4 \cdot 729 \\
4 \cdot 457 \\
3 \cdot 917 \\
3 \cdot 431 \\
4 \cdot 282\end{array}$ & $\begin{array}{l}4 \cdot 871 \\
4 \cdot 694 \\
4 \cdot 404 \\
3 \cdot 851 \\
3 \cdot 465 \\
4 \cdot 257\end{array}$ & $\begin{array}{l}4 \cdot 841 \\
4 \cdot 717 \\
4 \cdot 312 \\
3 \cdot 847 \\
3 \cdot 347 \\
4 \cdot 213\end{array}$ & $\begin{array}{l}4 \cdot 864 \\
4 \cdot 734 \\
4 \cdot 359 \\
3 \cdot 806 \\
3 \cdot 482 \\
4 \cdot 249\end{array}$ & $\begin{array}{l}4 \cdot 862 \\
4 \cdot 719 \\
4 \cdot 383 \\
3 \cdot 855 \\
3 \cdot 431 \\
4 \cdot 250\end{array}$ & $\begin{array}{l}4 \cdot 666 \\
4 \cdot 011 \\
3 \cdot 337 \\
3 \cdot 340 \\
2 \cdot 651 \\
3 \cdot 608\end{array}$ & $\begin{array}{l}4 \cdot 649 \\
3 \cdot 958 \\
3 \cdot 435 \\
3 \cdot 291 \\
2 \cdot 599 \\
3 \cdot 501\end{array}$ & $\begin{array}{l}4 \cdot 786 \\
3 \cdot 999 \\
3 \cdot 238 \\
3 \cdot 255 \\
2 \cdot 604 \\
3 \cdot 580\end{array}$ & $\begin{array}{l}4 \cdot 781 \\
4 \cdot 059 \\
3 \cdot 363 \\
3 \cdot 145 \\
2 \cdot 571 \\
3 \cdot 588\end{array}$ & $\begin{array}{l}4 \cdot 721 \\
4 \cdot 007 \\
3 \cdot 343 \\
3 \cdot 258 \\
2 \cdot 606 \\
3 \cdot 588\end{array}$ \\
\hline
\end{tabular}


LEARNING EFFFECT (F.V.C. \& F.E.V.)

FIGURE 1.

ALL VSITS - ALL MEN EXAMINED

(a) SCOTTISH COLLIERY.
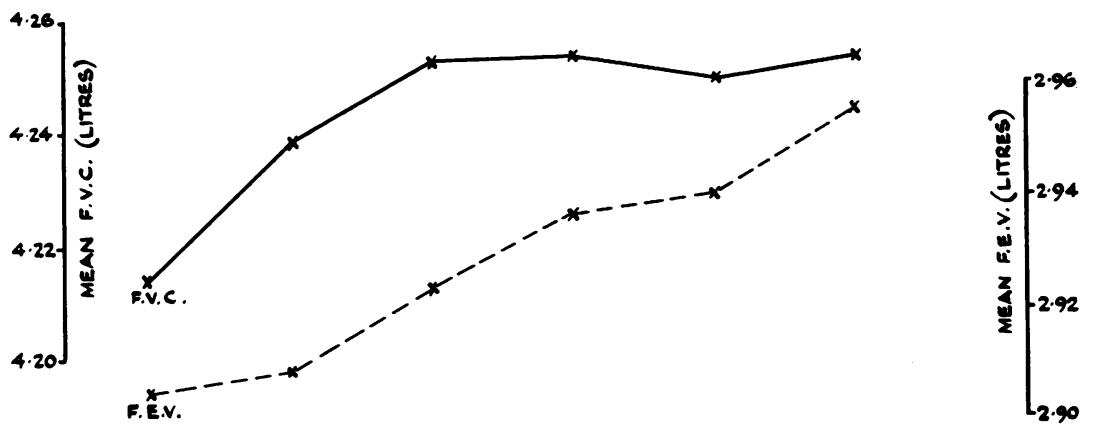

(b) SOUTH WALES COLLIERY.
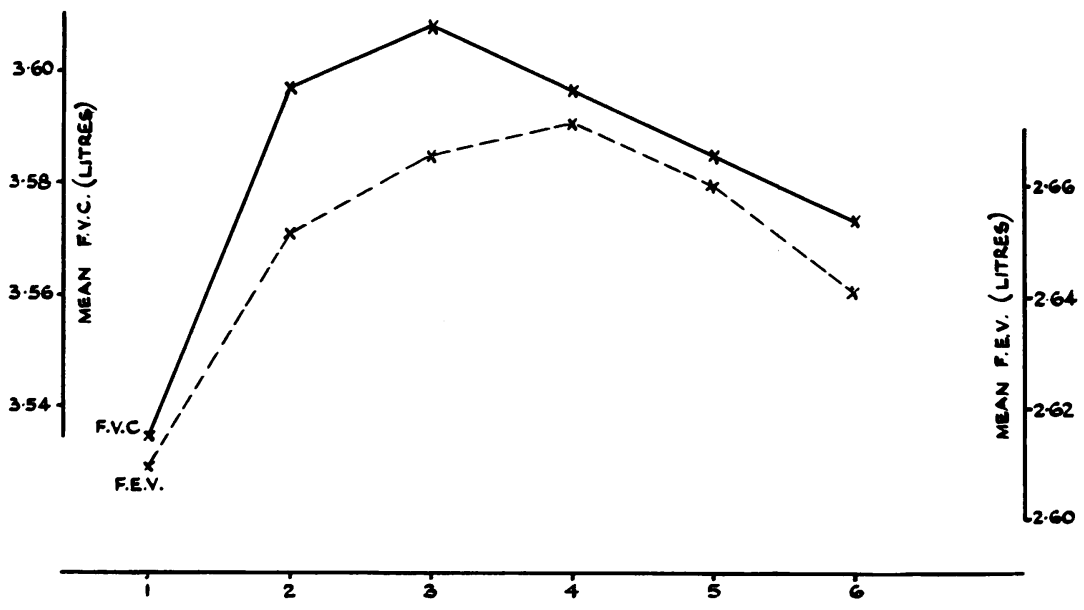

EXPIRATION No. 

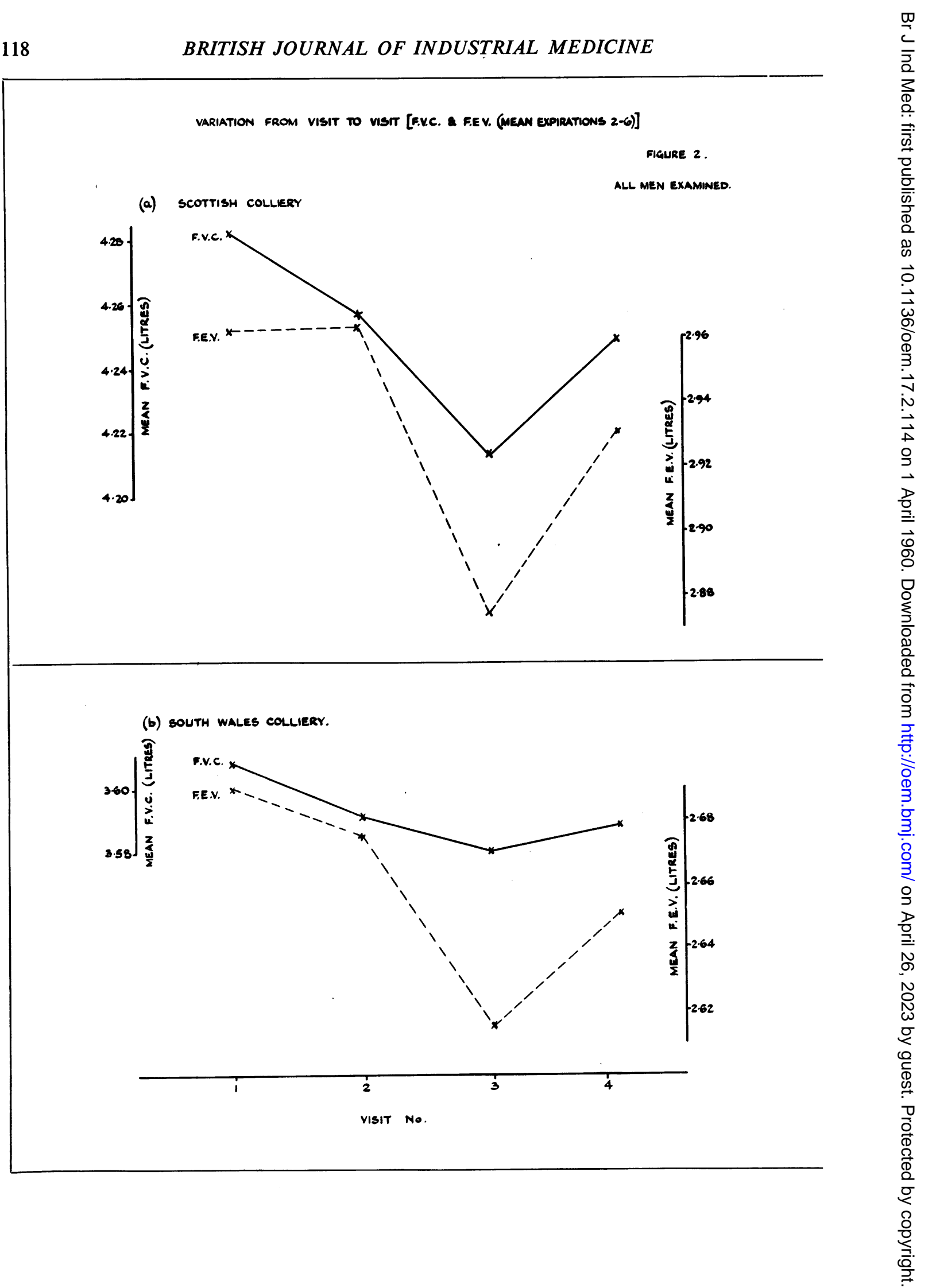
F.V.C. to fall on visit 3 was most marked for the older men.

(3) Variation with Time of Day.-The effect on the ventilatory capacity of the time of day at which the examination was carried out could not be measured using mean figures for all the men by shift, because the age distributions of the men on the three shifts were not the same. This effect was examined by comparing the average performance before work (visits 1 and 3) of the men who were examined on two different shifts. At neither colliery was there any significant diurnal variation.

(4) Variations with Day of the Week.-There was no evidence of any trend.

(5) Geographical Differences in Ventilatory Capacity.-From Figs. 1 and 2 it is seen that ventilatory capacities at the colliery in Fife were some $15 \%$ higher than corresponding values at the colliery in South Wales.

(6) The Repeatability of the Observations.The repeatability of the measurements of F.E.V. and F.V.C. from expiration to expiration may be expressed in terms of the standard deviation of the individual expirations on the same visit averaged over all the men under consideration (Table $4 a$ ). The standard deviations given in Table $4 b$ represent a summation of the variability from expiration to expiration on the same occasion (Table $4 a$ ) and the variability in average performance between the beginning and end of a shift. At the Scottish colliery the F.E.V. was only slightly less variable than the F.V.C. but at the Welsh colliery the F.E.V. was more reproducible than the F.V.C. The standard deviations given in Table $4 c$ represent a summation of the variability from day to day, between the beginning and end of the shift on the same day and from expiration to expiration on the same visit. A comparison with Table $4 b$ suggests that while variation, both in F.E.V. and F.V.C. from day to day at the Scottish colliery was small, that at the Welsh colliery was larger and the F.V.C. was the more variable of the two measurements. (The absolute value of the F.V.C. measurements was, of course, greater than that of F.E.V., and if this fact is taken into account, it is apparent that the proportional variation of F.V.C. was very little different and if anything slightly smaller than that of the F.E.V.)

(B) Weight and Height.-The differences between observers were negligible.

Weight.-Although there were wide individual variations, there was an average loss of weight of $1 \cdot 15 \mathrm{lb}$. during a shift. The greatest losses were in elderly faceworkers.

Height.-Between the beginning and end of a shift there was an average fall in standing and sitting height of $0.25 \mathrm{~cm}$. The greatest falls in standing and sitting height were in young faceworkers.

(C) Answers to Questionnaire.-In general the answers obtained by doctor and clerk were in close agreement. A summation is given in Table 5 of the replies to individual questions.

\section{Discussion}

The work of Fry, Ebert, Stead, and Brown (1954) and Hyatt, Schilder, and Fry (1958) suggests that the degree of lung inflation may affect the ventilatory capacity. Thus the observed rise in F.E.V. and F.V.C. with expiration number may have been due to the stretching of the lung by the successive inspirations. This explanation would not be inconsistent with the findings that the rise was still discernible at the fourth visit, was greater in faceworkers than in surfaceworkers, and was greater in younger men.

The low mean F.E.V. and F.V.C. at visit 3 (before a shift) is difficult to explain. The decrease was most

TABLE 4*

REPEATABILITY OF MEASURE MENTS OF F.E.V. AND F.V.C. (EXPIRATIONS 2-6)

\begin{tabular}{|c|c|c|c|c|c|c|}
\hline Colliery & Test & Visit 1 & Visit 2 & Visit 3 & Visit 4 & All Visits \\
\hline \multicolumn{7}{|c|}{ (a) From expiration to expiration on the same visit } \\
\hline $\begin{array}{l}\text { Scottish } \\
\text { South Wales }\end{array}$ & $\begin{array}{l}\text { F.E.V. } \\
\text { F.V.C. } \\
\text { F.E.V. } \\
\text { F.V.C. }\end{array}$ & $\begin{array}{l}0.15 \\
0.15 \\
0.20 \\
0.20\end{array}$ & $\begin{array}{l}0.14 \\
0.14 \\
0.19 \\
0.22\end{array}$ & $\begin{array}{l}0.12 \\
0.13 \\
0.13 \\
0.16\end{array}$ & $\begin{array}{l}0.11 \\
0.13 \\
0.12 \\
0.14\end{array}$ & $\begin{array}{l}0.13 \\
0.14 \\
0.17 \\
0.18\end{array}$ \\
\hline Test & Scottish Colliery & S. Wales Colliery & \multicolumn{2}{|c|}{ Test } & lliery & S. Wales Colliery \\
\hline
\end{tabular}

*Each entry is the standard deviation of a single expiration in litres. 
TABLE 5

ANALYSIS OF THE DISAGREEMENTS ON INDIVIDUAL QUESTIONS BY DOCTOR AND CLERK ON RESPIRATORY SYMPTOMS QUESTIONNAIRE

\begin{tabular}{|c|c|c|c|c|c|c|c|c|}
\hline \multirow{3}{*}{ Question } & \multicolumn{4}{|c|}{ Scottish Colliery } & \multicolumn{4}{|c|}{ South Wales Colliery } \\
\hline & \multicolumn{2}{|c|}{ Doctor } & \multicolumn{2}{|c|}{ Clerk } & \multicolumn{2}{|c|}{ Doctor } & \multicolumn{2}{|c|}{ Clerk } \\
\hline & Yes & No & Yes & No & Yes & No & Yes & No \\
\hline $\begin{array}{l}\text { Coughing } \\
\text { 1. Do you cough when you get up or } \\
\text { first thing in the morning? } \\
\text { 2. Do you cough during the rest of the } \\
\text { day? I don't mean at the end of the } \\
\text { shift } \\
\text { 3. Do you cough like this on most days } \\
\text { for as much as } 3 \text { months in the year? } \\
\text { Phlegm } \\
\text { 4. Do you bring up phlegm when you } \\
\text { get up or first thing in the morning? } \\
\text { 5. Do you bring up phlegm during the } \\
\text { rest of the day? } \\
\text { 6. Do you bring up phlegm like this on } \\
\text { most days for as much as } 3 \text { months in } \\
\text { the year? } \\
\text { Breathlessness } \\
\text { 7. Do you have to walk slower than } \\
\text { other people on the level? } \\
\text { Wheezing } \\
\text { 8. Do you ever have wheezing or } \\
\text { whistling in your chest?-I don't } \\
\text { mean when you have a cold } \\
\text { Weather } \\
\text { 9. Does the weather affect your chest? } \\
\text { Smoking } \\
\text { 10. Do you smoke? } \\
\text { 11. If no: have you ever smoked as much } \\
\text { as } 1 \text { cigarette a day for } 1 \text { year? } \\
\text { Illness In the last } 3 \text { years have you had a } \\
\text { 12. In thest illness that has kept you off } \\
\text { chest } \\
\text { work for more than a week? }\end{array}$ & $\begin{array}{l}36 \\
15 \\
27 \\
31 \\
23 \\
24 \\
10\end{array}$ & $\begin{array}{l}39 \\
60 \\
48 \\
44 \\
52 \\
51 \\
65\end{array}$ & $\begin{array}{l}28 \\
20 \\
20 \\
28 \\
26 \\
20 \\
11\end{array}$ & $\begin{array}{l}47 \\
55 \\
55 \\
47 \\
49 \\
55\end{array}$ & $\begin{array}{l}39 \\
17 \\
33 \\
30 \\
15 \\
27 \\
29\end{array}$ & $\begin{array}{l}37 \\
59 \\
43 \\
46 \\
61 \\
49\end{array}$ & $\begin{array}{l}31 \\
16 \\
33 \\
30 \\
13 \\
26 \\
26\end{array}$ & $\begin{array}{l}45 \\
60 \\
43 \\
46 \\
63 \\
50\end{array}$ \\
\hline
\end{tabular}

marked in faceworkers and older men. It is unlikely to have been caused by atmospheric conditions because visits 3 and 4 were on the same day for any one man and on different days for different men. Furthermore, local meteorological office records do not suggest that the atmospheric conditions on the second weeks of both the Scottish and Welsh trials differed consistently from those on the corresponding previous weeks.

Gielen (1957), McKerrow et al. (1958), and Worth, Valentin, Venrath, Gasthaus, and Hoffmann (1956) found a tendency for the ventilatory capacity to increase during a working shift in coal-miners; these observations were not confirmed in the present study. In contrast to the effect noted in men suffering from byssinosis (Schilling, Hughes, Dingwall-Fordyce, and Gilson, 1955; McKerrow et al., 1958) the ventilatory capacity of coal-miners was not related to the day of the week.

The simplest explanation of the higher ventilatory capacities in Scotland than in South Wales would be that there were differences between observers or instruments. In view of previous knowledge of the similar findings of Higgins and Cochran (1958) great care was taken before the experiment to minimize the possibility of a difference in the instruments having been responsible. The possi- bility remains that the responsibility for the apparent geographical differences lay with the inexperience of the observers. With the apparatus used, readings of F.E.V. were more easy to observe accurately than those of F.V.C. and, correspondingly, the differences between the Scottish and Welsh F.E.V.s and F.V.C.s were $10 \%$ and $18 \%$ respectively. As judged by the repeatability of the observations (Table 4), the observer at the Welsh colliery was considerably less competent than the one at the Scottish colliery. A difference in air temperature of $10^{\circ} \mathrm{C}$. between Scotland and Wales could not have produced more than a $5 \%$ discrepancy in air volumes. Furthermore, the Scottish and Welsh vehicles and other equipment were identical and the water around the spirometer bells was kept at $20 \pm 2{ }^{\circ} \mathrm{C}$. While the standing height of the Scottish men was greater by more than $3 \mathrm{~cm}$., their sitting height was only $1 \mathrm{~cm}$. greater so that nearly all the height difference must have been due to a difference in length of the legs (Higgins and Cochran, 1958); the mean weight of the Scotsmen was only $5 \mathrm{lb}$. more than that of the Welshmen. This leaves most of the difference in ventilatory capacity still to be accounted for. Unlike the findings of Higgins and Cochran, in the present study the prevalence of respiratory symptoms was higher in South Wales than in Scotland and 
this may have been related to the difference in ventilatory capacities found.

Differences in procedure and apparatus make it difficult to compare the repeatability of the ventilatory capacity measurements with that observed by other workers (Gilson and Hugh-Jones, 1949); Gray, Barnum, Matheson, and Spies, 1950; Friend, 1955). However, Higgins, Oldham, Merrick, and Dunsdon (1956), with apparatus similar to that used in the present study, obtained closer repeatability, presumably due to their greater experience in its use.

The fall in height during a shift was probably the gradual diurnal fall in height while in the erect posture (Backman, 1924). In agreement with the findings of Backman, it was greater in younger men.

We are indebted to the National Coal Board for permission to publish this paper.

\section{REFERENCES}

Backman, G. (1924). C.R. Soc. Biol. (Paris), 90, 1118.

Carpenter, R. G., Cochrane, A. L., Gilson, J. C., and Higgins, I. T. T. (1956). Brit. J. industr. Med., 13, 166.

Fay, J. W. J. (1957) Nature (Lond.), 180, 309.

F, and Rae, S. (1959). Ann. Occup. Hyg., 1, 149.

Friend, J. (1955). Thorax, 10, 359.

Fry, D. L., Ebert, R. V., Stead, W. W., and Brown, C. C. (1954). Amer. J. Med. 16, 80

Gaensler, E. A. (195i). Amer. Rev. Tuberc, 64, 256.

Gielen, E. (1957). Institut d' Hygiène des Mines, Hasselt, Communication No. 145.

Gilson J C . and Ho. 14J.

Gray, J. S., Barnum, D. R., Matheson, H. W., and Spies, S. N. (1950) J. clin. Invest., $29,677$.

Higgins. I. T. Invest., 29, Cochran, J. B. (1958). Tubercle (Lond.), 39, 296.

Oldham, P. D., Cochrane, A. L., and Gilson, J. C. (1956). Brit. med. J., 2, 904.

-, - Merrick, A. J., and Dunsdon, M. I. (1956). Brit. J. Prev. Soc. Med. 10, 32

Hyatt, R. E., Schilder, D. P., and Fry, D. L. (1958). J. appl. Physiol., 13,331 .

McKerrow, C. B., McDermott, M., Gilson, J. C., and Schilling, R. S. F. (1958). Brit. J. industr. Med., 15, 75.'

Schilling, R. S. F., Hughes, J. P. W. Dingwall-Fordyce, I., and Gilson, J. F., Hughes, J. P. P. W., 1955 , Did

Wood, C. H. (1958). Trans. Ass. Industr. med. Offrs, 8, 67.

Worth, G., Valentin, H., Venrath, H., Gasthaus, L., and Hoffmann, H. (1956). Arch. Gewerbepath. Gewerbehyg., 14, 269. 